\title{
Interactive Boards and their Function in Education
}

\author{
doi:10.3991/ijac.v2i1.572 \\ István Füvesi \\ University of Szeged, Szeged, Hungary
}

\begin{abstract}
In our accelerating world even education has become market-oriented. Learners have to acquire greater and greater amount of knowledge while the number of contact lessons, especially in higher education, become less and less. That is why giving particular information belonging to a certain topic should be raised - one method for this would be visualisation. This means that lectures would be structured in a way that the usual verbal lessons are supplemented by diversed and spectacular visual information. If the informations were followed by pictures, such as diversed diagrams and shown in an interactive way, accompanied by sound effects, the efficacy of teaching would get intensified. The fact that education-supporting new means and circumstances of learning, calls for changes in the methodology of teaching and learning; the educators are required to apply new teaching strategies. Here we would like to present the means and use of Informational and Communicational Technology (in the following: ICT), applied in informatics major. Besides, we also intend to introduce a new framework which plays an important role in forwarding learning material to students. An international lecture course serves as basis for the complex introduction of this framework.
\end{abstract}

Index Terms-Bluetooth, electronic learning, ICT, Interactive table, iPanel, Movie Maker, project method, Table PC, team-work.

\section{The Appearance AND SPREAd OF NeW TOOLS IN THE WORLD}

Traditional education, in which the teacher presents the material in front of a group of learners with the single help of a board has recently transformed.

\section{A. New tools}

First, simple blackboards with chalks have given place to 'white boards' on which you can write with felt tip pens. Later several kinds of projectors have appeared in education (slide projectors, overhead projectors etc.). In classrooms -equipped with televisions- one could not properly see visual information, due to low light-strength. Thus video-assisted education could only be applied in darkened room - which is not fit for learning.

In parallel with the expeditious development of informatics and the spread of computers- the new generation of projectors have arrived. Such projectors can visualize the information shown on the computer screen in a satisfactory quality. There have programs which can display spectacular presentation and now even the projection of movies are possible. Here we would not like to discuss the obviously emerging disadvantages of applying multimedia instruments in education, but to show numerous advantages there are. These benefits are presented from the teacher's and the learner's point of view. For instance, a professor can use a prepared and easily changeable multimedia material several times, and students can also inspect such materials limitlessly.

Such range of means has already underlined the emerging alternative form of education: distant learning. By cancelling or lowering the number of contact lessons the expenses of teaching can be reduced remarkably. Evolving and spreading TabletPC has provided a more colourful methodology in education as well.
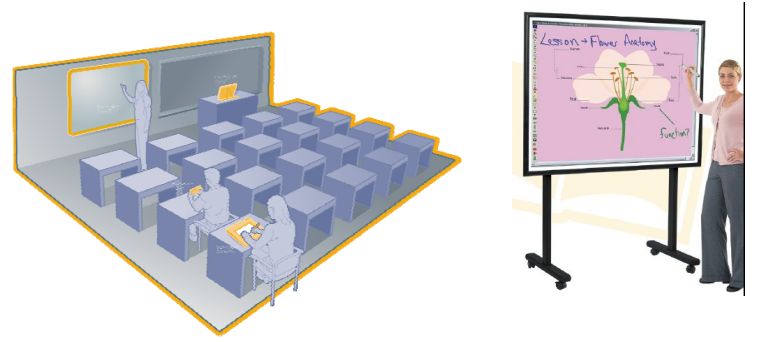

Figure 1. Interactive lecture in the interactive lecture room

The development in informatics, projecting technology and sensor technology, and their integration has made possible of the creation of a new teaching instrument: the interactive board. This is an implement which links the board with a PC and a projector, with the help of a certain software. Thus it is possible to control the computer through the board and the content that can be found on the board can be saved as well. Practically, this means that one not only can see the computer's screen on the special board but with the help of the board's sensors one can send visual information from the board to the computer as well. This way, as a reaction to the signals, the computer can change the picture that is visible on the board. Now the 'electronic slate' becomes a reality. With the help of this instrument not only you can project previously prepared materials but you can also draw, write, delete in presentation materials. The system is capable of storing and presenting any, previously taken and structured pictures which could not or could hardly be drawn by the instructor. These pictures can be modified during the lecture, thus making the presentation spectacular and live, which leads to a higher level of attention. With the help of interactive boards, it is possible to eliminate usual problematic points of a lecture, for instance a very lively clip where with earlier technology lecturers would have to make changes by clicking while with the interactive board they -themselves- trace the picture on the board, thus providing enough time for the audience to follow. 


\section{B. Interactive tables in the world}

Interactive boards can be grouped by the used technology, the way of projection and the instrument of writing. They can be different in sizes, and the users get these boards through a lot of distributors from a lot of manufacturers. By their tehnology we can discern six bigger types: rezistive, electro-magnetic, capacitive, laser, ultra-sonic and optical. By the way of projection there are two major categories: front projection and rear projection. Boards from the rear projection get the picture from behind by the help of a built-in projector and mirrors. That makes the picture to have a constant size. The front projection boards use separate projector, so the size of the picture depends on the distance between the projector and the board. The boards can be traceable by a special pen or our fingers, that's hanging on the side of the board.

The different types of boards, and the permeation in continents and nations will be discussed here in this lecture. A CalComp Interwrite board and its accessories help the presentation.

\section{Additional tools of the interactive tables}

The range of facilities provided by the interactive whiteboard can be broadened by further tools.
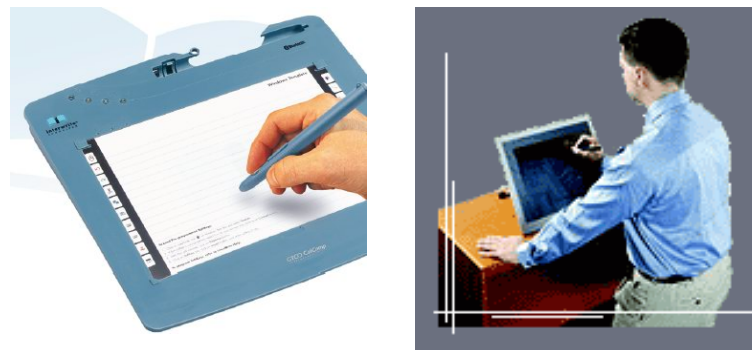

Figure 2. Schoolpad and iPanel

Main parameters of SchoolPad:

- A work plane of 6" x 8" (15.2 x $20.3 \mathrm{~cm})$.

- Connection to the system via Bluetooth /wireless/ or USB-cable.

- Connection with up to 7 Schoolpads, within a range of 90 metres.

- Up to 40 hours of use before having to recharge.

- It is possible to use and control the whiteboard and any application running on the computer from any point of the classroom.

- There is a possibility for students to take over and participate actively in the course of the class.

- It makes it easier to keep the attention of the students in class.

Although the SchoolPad raises the standard of education, there are, of course, hardships as well. The picture cannot be seen on the SchoolPad that is displayed by the computer; therefore, you have to click with the pen blindly. It is not an easy task if, for instance, you would like to point at an icon. Remember, however, that it was hard to operate the mouse at first as well, but we have become accustomed to that. (The InterWrite iPanel offers a real solution for the problem.)

The InterWrite iPanel makes quick data capture possible. On the interface of a hand-held LCD-screen, quick notes can be written and saved with the help of a special, pen-like device; which also allows the user to highlight sections that are considered important in the prepared material with only one stroke of a pen. The contents of the active whiteboard can also be displayed on the hand-held screens; and the pupils or students can complement it with their own thoughts.

The GTCO InterWrite PRS is a quick student response system based on infrared connection. Students can respond to the teacher's questions with the press of a button, marking the answer they consider correct. The system processes the responds at once, and displays the results for both the teacher and the class. The quick and straightforward feedback raises the level of co-operation and productivity within the group. By storing the results separately for each student, it becomes possible to support the evaluating and grading of students electronically. The $\mathbf{P R S}^{\mathbf{R F}}$ radio frequency system has a wider range of facilities as well: it is able to interpret multi-question sessions, and due to the screen and the keyboard, it is also possible to ask actual numbers (results of calculations, dates etc) or words (names, places etc) without giving 2-35 or more choices, which leaves virtually no possibilities for guessing.
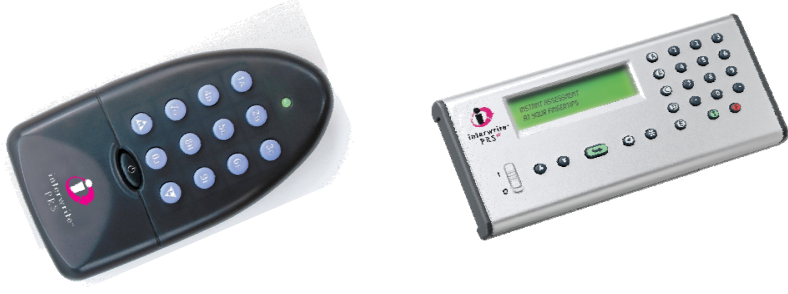

Figure 3. InterWrite PRS and $\mathrm{PRS}^{\mathrm{RF}}$ response systems

After getting to know the boards and the softwares connected to them, instructors can involve this great instrument into the teaching processes - either by applying their own materials, prepared by them, or free or purchased ones.

\section{The Appearance of a New Teaching Method}

The project method and its synonyms have no unanimously accepted definition in the pedagogical practice. The pedagogues are teaching with the purpose of diversity and alteration without realizing that they put the project method, the project pedagogy into practice.

Usually the Chicago University/1896!/ is named as the birth place of project pedagogy and in the past 100 years there were countless attempts to define it accurately in the native and the foreign special literature as well. Let's see now the introduction of the Pedagogical Project Company /PPC/ and one possible definition of project education!

The PPC was established in 1998 at Kecskemét, Ref. [15], and its aim is to clarify the theory of project pedagogy, to iniciate researches, to popularize and to have it professionally acknowledged in Hungary.

The project education is a learning-teaching strategy, the elaboration of a problem or theme accepted or chosen by the students, which generally happens in groups, ceasing and abolishing the traditional frameworks of class and lesson; in every case the result is a presentable material or intellectual creation or product; and it consists of the following well separable sections: choosing a theme, making a plan (determination of aims and tasks), organizing, collecting data, elaborating the theme, 
compiling the product in a presentable form, evaluation of the project, correction, presentation of the product, making it public, activities after finishing the project.

But we can say that the project pedagogy is the multicolourness by itself. A colourful whirling, which can be known by whom is inside of it: the learning of adventure - the adventure of learning. With this short representation we have no more purpose, but to direct the attention to this method and to its possibly to productive connection with informatics.

\section{A. Tendencies in the renewing tertiary education}

In higher education, there can be found global tendencies, along which the university education systems of the world are transforming. Tertiary education is ceased to be the scene of élite instruction, but it is becoming more and more of a mass education. The instruction is becoming multilevelled: high level vocational education, BSc (Bachelor of Science), MSc (Master of Science), PhD school. The conception of learning for the whole life is succeeded by the view of life-long learning. The tertiary education gives the bases, which are required for this and develops those capabilities, which are indispensable for the continuous professional renewing. The training besides work is becoming general. The correspondence, the tutorial and the vocational training get more and more emphasis in tertiary education. The professional structures, ratios are changing. The economist, jurist, informatic, science trainings are coming to the foreground, while the rates of human training are decreasing. Besides professional competences, the acceleration of scientifictechnical progress requires the improvement, development of methodological (recognizing and solving problems, independence, abilities to make a decision) and social (abilities to communicate and to cooperate) competences. The accelerating pace of the expansion and obsolescence of science and informatic knowledge highlights the ability of acquiring knowledge and the positive attitude to learning in the higher education as well. The centre of training becomes the aquiring of knowledge or, many cases, the research. The credit- and module system have become general. According to this, the renewing of the education must cover the change of viewpoint and function both on behalf of the teachers and the students. A new type of relationship between teacher and student has to develop.

This change of view requires from the teachers an attitude, which is direct help and controll learning. They do not just teach, but organize, manage the learning processes.

With the domination of the new strategies organizing learning to expanse, the scenes of learning in time and space is getting more and more important. The forming of those places, which are suitable for learning alone or in small groups are becoming more important in educational institutions, at workplaces, in libraries, in mediacentres, at research places, at home. The role of accessibility and usefulness of the source of knowledge is increasing on the computer networks.

The credit- and module system includes some of the elements of the project pedagogy. So in tertiary education the methods to organize learning will become determining and they are putting forward the responsibility of the individual. Therefore the pupils must be prepared for this learning strategy by secondary school. The pedagogue aspirants necessarily must get acquainted with the application of project pedagogy.

\section{B. The experiences of groupwork}

Some of our students, mainly with the faculty of teaching and communications are also working in teams for several years to make the education of informatics colourful. In the lecture there will be presented parts of the results and the works of the course where the students worked in groups of four (several hundreds per semester). The examples (presentations, films) show the possibilities of informatics in the special subject education and the importance of the newest multimedia tools $[1,2,4,5,6,7$, $8,9,10,11,12,13,14]$.

Our aim is to obtain that we train such teachers, who use informatics, multimedia with routine as a tool in the course of teaching their special subjects. Who are able to put into their lectures the professionally controlled curriculum elements published on CDs, on the web, by this means making them more colourful, more effective and more interesting. Making the material of their lectures accessible, they can ensure their pupils to study according to their needs (optional schedule and optional period of time).

\section{FRAMEWORKS AND THEIR USE}

Especially in higher education, it is highly important to help students to get registered for a given course and receiving all the necessary information and study material. In Hungary there are two educational frameworks in use, one of them is Coospace, Ref. [16].

\section{A. A CooSpace}

In this framework there are separate scenes connected to each course, through which participants of the course can communicate, download materials, read lists, handouts - or upload their homework and receive grading. They can also follow the deadlines for their tasks or important dates concerning their lectures or seminars.

CooSpace offers virtual spaces to support actual learning processes. A separate space for each course provides a possibility to the users for communication, downloading source materials, schedules and learning materials, uploading and evaluating pieces of homework, and keeping an account of deadlines and times of lectures, seminars or other practice sessions.

The main applications of CooSpace provide possibilities to students, teachers and everyone. The latter category includes grouping objects, billboards and managing personal details. The following details of the users can be accessed publicly: name, username, e-mail address and pictures.

The facilities available to students make it easier to submit assignments, complete practices or exam tests.

Submitting an assignment: Assignments are given by the lecturer that can be uploaded. It is more simpler than submitting a task via email. The file formats can be optional. The system preserves the assignments handed in, the sender can be identified precisely. The instructor can ask the student to revise the assignment submitted for evaluation with his or her comments. The instructor can then evaluate the revised assignment, which appears immediately in the system. 
Submitting an assignment can have two steps: first, the student hands in the assignment only for evaluation. Second, the material gets revised according to the teacher's instructions and that gets submitted as a final assignment.

Completing/practice and exam/ tests: Alongside the other tasks, the instructor can assign to students to complete tests. These need to be filled in within the time limit set by the instructor. There are two types of tests: Exam tests to be completed within the time limit set by the instructor (the results are recorded). Self-check tests to test knowledge (these can be completed more than once, the results are not recorded). The system evaluates the tests automatically according to the algorithms given by the instructor, and displays the results in a separate window.

Question types: simple-choice, multiple-choice, or more questions per page: textual, numerical, finding pairs. There is only one correct answer; the letters or numbers have to be given accurately, otherwise the system evaluates the answer as incorrect. The questions (correct and incorrect answers) can be checked again with the evaluation.

Completing an exam test: The test can be started by giving a password. The process cannot be aborted by closing the window once you have started, but there is a possibility to contact the person who compiled the test if a problem occurs. Alongside general information /the time of the availability of the test, the time limit set for the test, the maximum number of completions/, the deadline for correction is also provided.

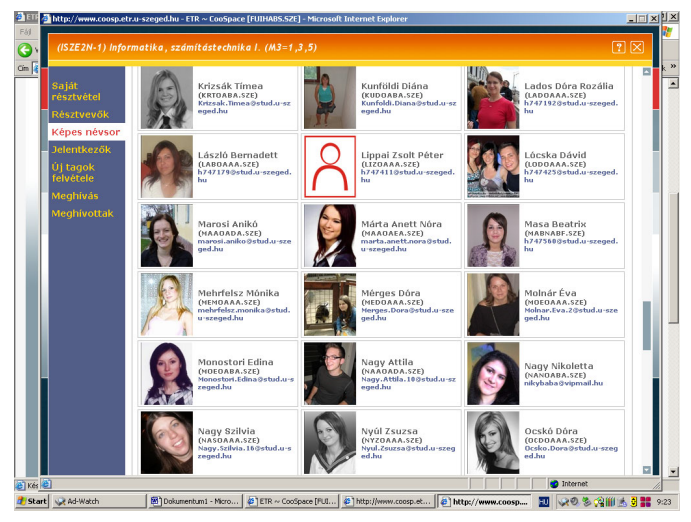

Figure 4. An impressive facility of CooSpace

Facilities provided for instructors: creating an internal space, uploading documents, assigning and evaluating tasks, creating and managing forums, creating and managing a billboard, creating and managing records of presence, question banks, options of space, creating test sheets, creating and managing exam tests, using the media collection.

\section{B. International use of the frame system}

I held a lecture titled 'Cooperative Learning in ICT Tools Supported Environment' at the Johannes Kepler University, Linz in 2007 to an international audience within the CEEPUS program. The aims of the course were the following: Offering an overview of ICT tools and demonstrating their practical use; Introducing an educational frame system, CooSpace, and its use; Introducing the project method.
The course had been available for enrolment at [3] half a year earlier, and the space was activated one week before its actual start.

The students could attach their pictures at the first meting, and groups were formed. Then, the teams could begin and plan their work. The last meeting functioned as a consul-tation, where the half-complete works were examined to-gether, and the necessary changes were discussed. The foll-owing consultations took place on CooSpace. The students submitted the finalized material within five weeks, and they were informed about the results on CooSpace again.

The content of the course: Teams of three had to be formed, and a lecture's material needed to be prepared from the topics established in the first class, different for each team, within 6 weeks.

Softwares that could be used and applied for preparing the material and methods were discussed in the lectures of the course.

The material of the lectures of the course was available for students on the CooSpace frame system, which could be accessed ONLY by students who registered, and had a username and a password. These were assigned in the first lecture, which also introduced the operation of the system to the students.

Main topics: PowerPoint, Movie Maker, ICT, Tablet PC, Interactive whiteboard, Bluetooth, Electronic learning, Project method, Team-work, Digital Object Identifier.

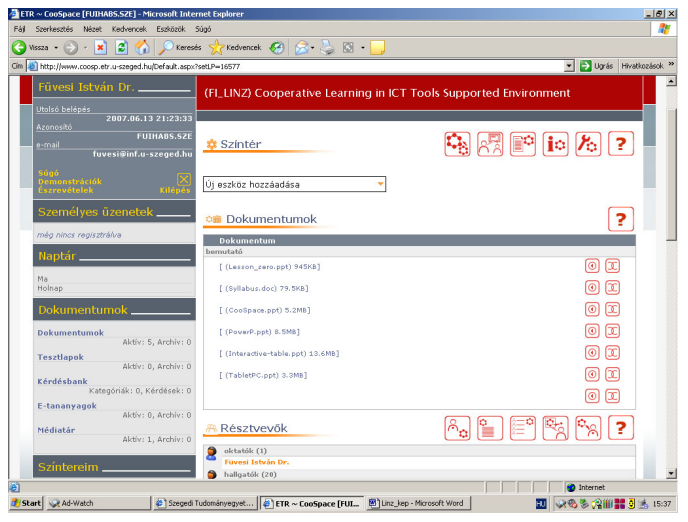

Figure 5. The scene of the course

The complete demo material was accessible in English, and the parameters of CooSpace were set to allow students to download it 5 minutes after the lectures.

\section{SUMMARY AND SEARCHING FOR A LOOPHOLE}

Students, just like in Szeged, worked three in a group. Both the instructors' and the students' presentations included video parts which will be shown here during the lecture. There was significant interest concerning ICT instruments, especially among distant learners and seconddegree students. Last, but not least, interactive boards provide chances not only for usage in informatics major but also for presenting different language elements in a highly effective way. At the University of Szeged we are presenting the tools which are successfully involved into the education on a videotype.

In the last 15 years production of educational materials has been speeded up, but this variety, especially in the case of interactive boards, causes problems. Since in 
bigger countries particularly the inland manufacturers circulated a lot of boards of the same type, so schools, and somewhere regions as well began to use that very type. This makes installation easy, because most of the boards have their own softwares wich are not compatible with each other. The completion of the educational curriculums which are based on these hardwares and softwares, is a long process, and can be different in each country.

Though variety is welcome, it has several problems, especially in Hungary. From more than 10 boardtypes 5000 pieces are used, with a compound distribution among schools, moreover, within schools. The supply of 40.000 classrooms is scheemed by 2010. Schools can tender for such boards, and the distributors, also tenderwinners, transport the boards to the extent they are capable to do this. The variety of boards is increasing, but we're not heading for standardization. It would be better if the production of table-independent softwares and curriculums speeded up, otherwise underpaid and overloaded teachers will get to know and apply these products only very slowly.

The boards which were put into use will be discussed here in this lecture, but details about the way of actual use is difficult to collect. There is need for international cooperation in connection with changes in educational methodology and similarly for sharing experiences.

\section{ACKNOWLEDGMENT}

Thank you for all my students for recording the material of the lectures, and for the enthusiastic use of CooSpace.

\section{REFERENCES}

[1] A. Ringler, K. Vezendi, K. Füzesi, and I. Füvesi: "Multimedia In Health Education", 2nd International Conference on Information, 2003, Mansoura, Egypt.

[2] I. Füvesi and A. Ringler: "Team-work in special subject education support with multimedia", 4th International Conference on ELearning and 4th International Conference on Information (ICI-4), 2005, Kuala Lumpur, Malaysia.

[3] I. Füvesi: "Cooperative Learning in ICT Tools Supported Environment", CEEPUS, Johannes Kepler University, Linz, Ausztria, 2007, http://www.ssw.uni-linz.ac.at/Teaching/Lectures/ SpezialLVA/Fuevesi//

[4] I. Füvesi: "Szaktanárok informatikai felkészítése", TEE Szemle, a Tanárok Európai Egyesületének folyóirata, Veszprém, 2004, I. évfolyam 1. szám, pp. 9-14.
[5] I. Füvesi: "Informatika a szaktárgyi oktatás szolgálatában", Tanárok Európai Egyesülete I. országos konferencia, Veszprém, 2004, http://www.tee-aede.org .

[6] I. Füvesi and A. Ringler: "Multimédia a tanulás és a tanítás szolgálatában”, AgriaMédia 2004 Konferencia, Eger, 2004, Konferencia kiadvány, pp. 97-105.

[7] I. Füvesi: "Kapcsolatépítés határon túli magyar anyanyelvü tanárokkal és tanulókkal", TEE Szemle, a Tanárok Európai Egyesületének folyóirata, Veszprém, 2004, I. évfolyam 2. szám, pp. 3-7.

[8] I. Füvesi: “A szaktárgyi oktatás informatikai támogatása", Tanárok Európai Egyesülete I. Országos Konferencia anyaga, Veszprém, TEE Szemle, a Tanárok Európai Egyesületének folyóirata, Veszprém, 2004, I. évfolyam 2. szám, pp. 37-40.

[9] I. Füvesi: "Szerepvállalás a határon túli magyar anyanyelvü tanárok továbbképzésében”. PEDAGÓGUSKÉPZÉS, a Tanárképzök Szövetségének folyóirata, Budapest, 2005. évi 1. szám, pp. 85-89.

[10] I. Füvesi: “A tanárok felkészítése a számítógéppel támogatott oktatásra”, Matematika, fizika és számítástechnika oktatók XXX. Konferenciája, Pécs, 2006, Konferencia kiadvány, pp. 97-113.

[11] I. Füvesi: “A motiváció szerepe a kommunikáció szakosok informatikai képzésében”, Multimédia az oktatásban Konferencia, Kaposvár, 2006, Konferencia kiadvány, pp. 87-93.

[12] I. Füvesi: "Kooperatív tanulás ICT eszközökkel támogatott környezetben", AgriaMédia2006 Konferencia, Eger, 2006, Konferencia kiadvány, pp. 108-115.

[13] I. Füvesi: “CooSpace-en keresztül kopog az IKT az aktív táblán”, Multimédia az oktatásban Konferencia, Budapest, 2007, Konferencia kiadvány, pp. 49-55.

[14] I. Füvesi: "IKT kopog az aktív táblán”. MTA SZMAB Szakmódszertani Albizottság, III. Szakmódszertani Tanácskozás, Budapest, 2007, Konferencia kiadvány, pp. 27-33.

[15] G. Hegedüs, Á. Mayer, G. Szécsi, and B. Zombory: "Projektpedagógia", Kecskeméti Főiskola Tanítóképző Főiskolai Kar, 2002, pp. 1-223.

[16] http://www.etr.hu/CooSpace/

\section{AUTHOR}

I. Füvesi is with the Department of Informatics, University of Szeged, H 6720 Hungary ( e-mail: fuvesi@inf.u-szeged.hu).

This article was modified from a presentation at the the International Conference on E-Learning in the Workplace (ICELW2008) in New York, NY, USA, June 2008. Manuscript received 14 April 2008. Published as submitted by the author. 